\title{
Tyrosine-Protein Kinase JAK2
}

National Cancer Institute

\section{Source}

National Cancer Institute. Tyrosine-Protein Kinase JAK2. NCI Thesaurus. Code C28494.

Tyrosine-protein kinase JAK2 (1132 aa, $131 \mathrm{kDa})$ is encoded by the human JAK2 gene.

This protein is involved in immunity, tyrosine phosphorylation and signal transduction. 